\title{
Modern methods of forming an innovation strategy of the banking sector of the economy
}

\author{
Natalya Baydukova ${ }^{1,2}$, Oksana Belyantseva ${ }^{3}$, Elena Smorodina $^{3, *}$, Tatiana Sandyuk ${ }^{4}$, Elena \\ Melnikova $^{4}$ and Olesya Smirnova ${ }^{4}$ \\ ${ }^{1}$ Sankt-Petersburg State Economic University, 21, Sadovaya street, St. Petersburg, 191023, Russia \\ ${ }^{2}$ Sankt-Petersburg State University, 13B, Universitetskaya Emb., St Petersburg 199034, Russia \\ ${ }^{3}$ Voronezh State Technical University, Moscow Avenue, 14, Voronezh, 394026, Russia \\ ${ }^{4}$ State University of Technologies and Management named after K.G.Razumovsky (Bashkir branch), \\ Smolenskaya Street, 34, Meleuz, 453850, Russia
}

\begin{abstract}
The aim of this study is to develop modern approaches to the formation of innovation strategies of credit institutions based on nontechnological innovations. As a result of the analysis of theoretical material, a conceptual model was developed for the formation of the innovation policy of credit institutions, and the impact of nontechnological innovations on the efficiency of their functioning was assessed. Based on the classification of the portfolio of innovation tools, a mathematical model has been developed and a methodology has been proposed for operative control over the process of implementing a set of innovation strategies included in the development plan of a credit institution.
\end{abstract}

\section{Introduction}

In a competitive environment, the activities of credit institutions are associated with the influence of a large number of various factors that have a direct impact on their development. The most significant of these are the globalization of world markets, a reduction in the life cycle of banking products, increased competition, etc.

In accordance with the dynamically changing environmental conditions, any credit institution as a full-fledged market participant is forced to change itself, becoming the initiator of its own organizational changes. It is obvious that the changes should not proceed spontaneously, they must be carried out systematically and within the framework of solving the problems of modernization of the management and economic activities of credit institutions. One of the directions for the success of such changes is the strategic planning and management of the innovative development of credit institutions, which are based on evolutionary and revolutionary strategies [1].

In credit institutions that implement evolutionary strategies, the main focus of developers is aimed at finding methods and tools that allow for more productive and efficient use of initial competitive advantages. In economics, the initial (resource)

\footnotetext{
* Corresponding author: belyaeva-sv@mail.ru
} 
competitive advantages, as a rule, relate to Level 1 assets (lower), which have a trend of being quickly exhausted or copied by competitors.

\section{Materials and methods}

The process of modernization of the management system in credit institutions and their transition to modern management methods and tools often focuses on improving the same initial resource advantages. At the same time, the role of such components of the strategic potential of credit institutions as organizational and economic (managerial) innovations, which in some cases are called "non-technological", is clearly underestimated. This is confirmed by the results of analysis on the use of non-technological innovations by commercial banks. In particular, of the large list of non-technological innovations identified in the research process, most commercial banks use only three or four types of managerial innovations tested in practice (Table 1).

Table 1. The structure of the most popular non-technological innovations and their use in the innovation development strategies of a number of credit institutions.

\begin{tabular}{|c|c|c|c|c|c|c|c|c|c|c|}
\hline \multirow{2}{*}{$\begin{array}{l}\text { Strategy and } \\
\text { name of } \\
\text { innovation }\end{array}$} & \multirow{2}{*}{$\begin{array}{l}\text { Brief description of } \\
\text { innovation }\end{array}$} & \multirow[t]{2}{*}{ Strategy focus } & \multicolumn{8}{|c|}{ Credit institutions } \\
\hline & & & 1 & 2 & 3 & 4 & 5 & 6 & 7 & 8 \\
\hline $\begin{array}{c}\text { Business } \\
\text { Process } \\
\text { Reengineering }\end{array}$ & $\begin{array}{l}\text { Radical changes in } \\
\text { key business } \\
\text { processes }\end{array}$ & $\begin{array}{c}\text { Increase } \\
\text { productivity, quality } \\
\text { and cost reduction }\end{array}$ & + & + & & + & + & & & \\
\hline Benchmarking & $\begin{array}{c}\text { Introduction of best } \\
\text { management } \\
\text { practices }\end{array}$ & $\begin{array}{l}\text { Effective cost } \\
\text { management }\end{array}$ & & & & + & & & + & \\
\hline $\begin{array}{l}\text { Investing in } \\
\text { core } \\
\text { competencies }\end{array}$ & $\begin{array}{c}\text { Investing in } \\
\text { technology that } \\
\text { creates value for the } \\
\text { product }\end{array}$ & $\begin{array}{l}\text { Key customers, } \\
\text { increasing their } \\
\text { loyalty }\end{array}$ & & + & & & + & + & & + \\
\hline $\begin{array}{l}\text { Segmentation } \\
\text { of key } \\
\text { customers }\end{array}$ & $\begin{array}{l}\text { Division of the } \\
\text { markets into groups } \\
\text { of clients. }\end{array}$ & $\begin{array}{l}\text { Personalized } \\
\text { marketing }\end{array}$ & + & & + & & & + & & \\
\hline $\begin{array}{l}\text { Growth } \\
\text { strategies }\end{array}$ & $\begin{array}{l}\text { Directing resources } \\
\text { to ensure profit } \\
\text { growth }\end{array}$ & $\begin{array}{l}\text { Strategic planning, } \\
\text { innovation } \\
\text { management }\end{array}$ & + & + & & & + & & & + \\
\hline $\begin{array}{c}\text { Merger } \\
\text { strategy } \\
\text { (acquisition) }\end{array}$ & $\begin{array}{c}\text { Acquisition of } \\
\text { banks in order to } \\
\text { obtain synergies for } \\
\text { sales }\end{array}$ & $\begin{array}{c}\text { Strategic alliances, } \\
\text { mergers, } \\
\text { acquisitions }\end{array}$ & & & + & & & & + & \\
\hline $\begin{array}{c}\text { Strategic } \\
\text { planning } \\
\text { (innovation) }\end{array}$ & $\begin{array}{c}\text { Optimization of } \\
\text { business units, } \\
\text { optimal allocation } \\
\text { of resources } \\
\end{array}$ & $\begin{array}{l}\text { Key competencies, } \\
\text { scenario planning }\end{array}$ & & + & & + & & + & & \\
\hline $\begin{array}{c}\text { CRM } \\
\text { (relationship } \\
\text { management) } \\
\text { strategies } \\
\end{array}$ & $\begin{array}{l}\text { Retention and } \\
\text { "growing" the most } \\
\text { loyal customers }\end{array}$ & $\begin{array}{l}\text { Build up business } \\
\text { collaboration, } \\
\text { customer retention }\end{array}$ & & & & + & & & & \\
\hline $\begin{array}{l}\text { Total for a } \\
\text { group of } \\
\text { banks }\end{array}$ & & & 3 & 4 & 2 & 4 & 2 & 3 & 2 & 2 \\
\hline
\end{tabular}


One of the reasons for this phenomenon is the problem of ambiguity in the interpretation of the concept of "innovation", which significantly reduces the scope of using the latest management methods and tools in credit institutions.

For the real sector of the economy, it identifies three mandatory properties that characterize innovation: novelty; satisfaction of market demand; commercial viability. In contrast, in the banking sector, the concept of "innovation" has a broader meaning and includes an expanded range of mandatory properties inherent to the novelty [2].

This allows us to conclude that in the banking sector, the concept of "innovation" is applicable to all managerial innovations that have a positive economic or strategic effect manifested either in the growth of the customer base or in the growth of profits.

It is important to note that in the scientific literature, non-technological innovations are not even structured, not combined into a "innovation portfolio", which is extremely important when forming and choosing the most attractive strategies for the innovative development of credit institutions for different market segments in the context of their modernization.

Based on this, a conceptual model is proposed for the formation of the innovation policy of credit institutions when implementing evolutionary and revolutionary strategies (Figure $1)$.

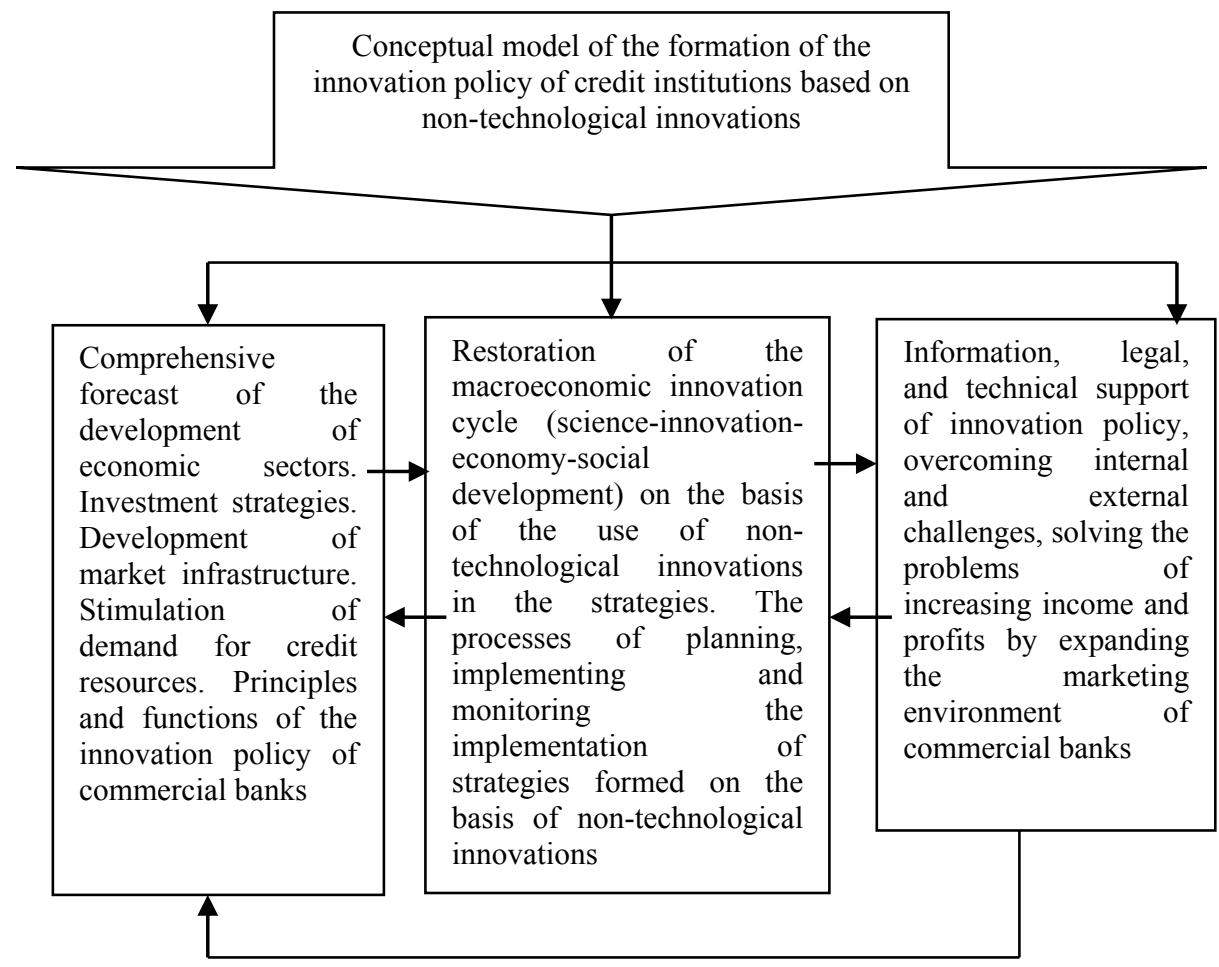

Fig. 1. The conceptual model of the formation of innovation policy of credit institutions.

In order for the proposed model to achieve its goals, effectively fulfill the intended role for a more active transition from an evolutionary type of development to an innovative (revolutionary) one, new integral approach was proposed to select directions of innovative development of credit institutions (Figure 2). 
Practice shows that neither the evolutionary nor the revolutionary type of modernization "alone" does not guarantee obtaining the results necessary for creation of a high-demand and high-quality banking product [4].

It is necessary to integrate these approaches with the simultaneous use of modern methods and organizational models. Such integration allows sparingly making a smooth transition from using strategies of primarily evolutionary type to strategies simultaneously based on Level 1 and Level 2 assets. Innovation strategies in this case may include the whole range of innovations, both of a technological, organizational and investment nature.

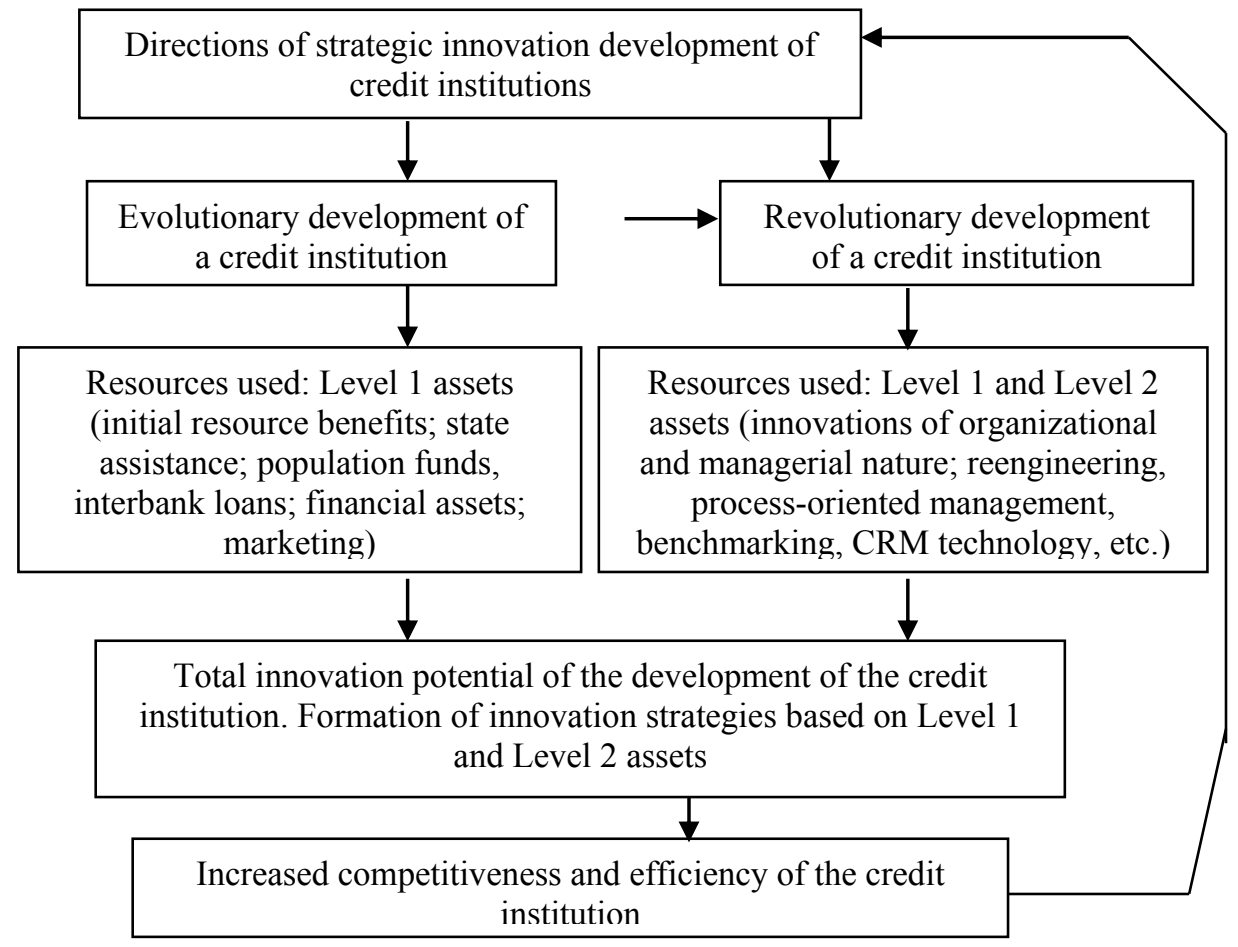

Fig. 2. Directions and formation of innovation strategies for the development of credit institutions.

The formation of innovation strategies is carried out within the framework of the existing legal and regulatory environment, the reproductive demand for banking services, and the use of demand-stimulating marketing mechanisms.

Based on the analysis of domestic and foreign experience in the use of nontechnological innovations in the banking sector of the economy, the author identified, categorized and combined in the "Innovation portfolio" a set of non-technological (managerial) innovations, which act as determining components of the strategic potential of competition credit institutions (Table 2).

Table 2. Portfolio of innovation tools for the implementation of a complex of non-technological innovations in banks' development strategies.

\begin{tabular}{|c|l|l|l|l|}
\hline Group & $\begin{array}{l}\text { Defining } \\
\text { innovation } \\
\text { tool }\end{array}$ & $\begin{array}{l}\text { Innovation tools } \\
\text { included in the } \\
\text { group }\end{array}$ & Brief description & \multicolumn{2}{|c|}{$\begin{array}{c}\text { Aims and objects of banking } \\
\text { management }\end{array}$} \\
\hline 1 & $\begin{array}{l}\text { Strategic } \\
\text { planning and } \\
\text { management } \\
\text { of innovation }\end{array}$ & $\begin{array}{l}\text { Growth } \\
\text { strategies; } \\
\text { knowledge } \\
\text { management; }\end{array}$ & $\begin{array}{l}\text { Determining the } \\
\text { status of the } \\
\text { business and the } \\
\text { distribution of }\end{array}$ & $\begin{array}{l}\text { Innovation management; corporate } \\
\text { intellectual capital management; } \\
\text { breakthrough } \\
\text { development funds; cost }\end{array}$ \\
\hline
\end{tabular}




\begin{tabular}{|c|c|c|c|c|}
\hline & $\begin{array}{l}\text { development } \\
\text { of credit } \\
\text { institutions }\end{array}$ & $\begin{array}{lr}\text { merge } & \text { teams; } \\
\text { mission } & \text { and } \\
\text { vision; } & \text { key } \\
\text { competences; } \\
\text { venture } \\
\text { financing }\end{array}$ & $\begin{array}{l}\text { limited resources; } \\
\text { ability to evaluate } \\
\text { alternatives to } \\
\text { increase } \\
\text { shareholder value }\end{array}$ & $\begin{array}{l}\text { management; transformation of } \\
\text { strategic goals; scenario planning; } \\
\text { key competencies; joint activities; } \\
\text { real options; ROA, ROI calculation; } \\
\text { direct investments }\end{array}$ \\
\hline 2 & $\begin{array}{l}\text { Business } \\
\text { process } \\
\text { reengineering }\end{array}$ & $\begin{array}{l}\text { Modern } \\
\text { management } \\
\text { methods and } \\
\text { tools }\end{array}$ & \begin{tabular}{|lr} 
Radical & changes in \\
key & business \\
processes &
\end{tabular} & $\begin{array}{l}\text { Reorganization of business } \\
\text { processes; disaggregation of } \\
\text { structures; reduction of time spent } \\
\text { on procedures; horizontal } \\
\text { organization }\end{array}$ \\
\hline 3 & $\begin{array}{l}\text { Process- } \\
\text { oriented } \\
\text { management }\end{array}$ & $\begin{array}{l}\text { Benchmarking; } \\
\text { balanced system } \\
\text { of performance } \\
\text { indicators; } \\
\text { banking } \\
\text { logistics; life } \\
\text { cycle } \\
\text { management }\end{array}$ & \begin{tabular}{|lr} 
Synchronization of \\
efforts of \\
parties & and \\
organization ran \\
cash of \\
continuous \\
$\begin{array}{lr}\text { exchange } \\
\text { information, } \\
\text { resources, services }\end{array}$ \\
\end{tabular} & $\begin{array}{l}\text { Cost management; competitive } \\
\text { analysis; management by objectives; } \\
\text { payment by results; development of } \\
\text { strategic balance; resource } \\
\text { management; cost management; } \\
\text { value chain analysis; e-commerce; } \\
\text { integration of survey participants }\end{array}$ \\
\hline 4 & $\begin{array}{l}\text { Relationship } \\
\text { management } \\
\text { (CRM- } \\
\text { technology) }\end{array}$ & $\begin{array}{l}\text { Direct } \\
\text { marketing; } \\
\text { electronic } \\
\text { collaboration }\end{array}$ & $\begin{array}{l}\text { Collect information } \\
\text { for better } \\
\text { understanding of } \\
\text { customers }\end{array}$ & $\begin{array}{l}\text { Business cooperation; customer } \\
\text { retention; customer segmentation; } \\
\text { activity management }\end{array}$ \\
\hline 5 & $\begin{array}{l}\text { Total Quality } \\
\text { Management } \\
\text { (TQM) }\end{array}$ & ISO 9001-2008 & \begin{tabular}{|ll} 
Submission & to \\
customer & \\
requirements; & \\
quality control & \\
\end{tabular} & $\begin{array}{l}\text { Quality teams; management through } \\
\text { control of quality management } \\
\text { processes }\end{array}$ \\
\hline 6 & \begin{tabular}{|l} 
Business unit \\
management
\end{tabular} & $\begin{array}{l}\text { Functional } \\
\text { control methods }\end{array}$ & $\begin{array}{l}\text { Distribution of } \\
\text { responsibility }\end{array}$ & Responsibility centers; profit centers \\
\hline
\end{tabular}

The above proposed classification and portfolio of non-technological tools recommended for modernization of management can be recommended to credit institutions for the formation of modern innovation policy.

At the same time, it is recommended to count the innovation potential of a credit institution as the result of summing up innovation capacities of an organizational, managerial and technological nature (Level 1 and Level 2 assets). Such integration of innovation assets of competition at various levels significantly enhances and accelerates the managerial impact of commercial banks on the potential consumer preferences of customers in relevant market segments (Figure 3).

The aggregate strategic innovation organizational and economic potential of a credit institution will be calculated using the formula 1:

$$
\Sigma \mathrm{SPb}=\mathrm{SPtp}+\mathrm{SPoep}+\mathrm{SPp}
$$

SPtp - current potential of a credit institution; SPoep - strategic productive potential of a credit institution; $\mathrm{SPp}$ - personnel strategic potential.

In this case, it is recommended to make an assessment of the efficiency of using the design innovation potential of a credit institution on the basis of the calculation of the integral factor using formula 2: 


$$
K=\frac{\sum_{i=1}^{n} a_{i} * b_{i}}{\sum_{i=1}^{n} a_{i} * b_{\max }} * 100 \%
$$

where: $K$ - integral indicator of the credit institution success, points; $a_{i}$ - the level of priority in the use of a specific set of innovations, points; $b_{i}$ - expert assessment of the degree of feasibility of innovations, points; $b_{\max }$ the maximum possible assessment of the degree of feasibility of a complex of innovations, points.

Organizational and economic innovation potential of the bank

(SPoep)

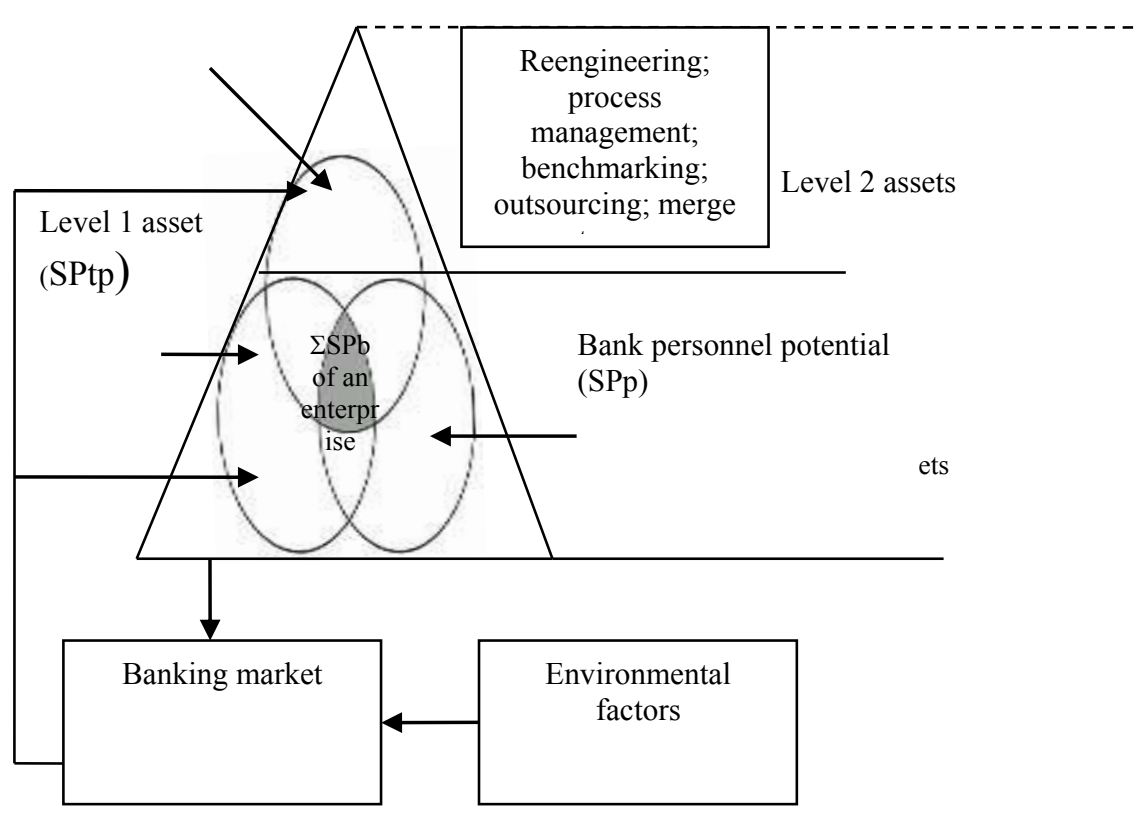

Fig. 3. The model of formation of the organizational and economic component of the innovation potential of a commercial bank on the basis of the integration of Level 1 and Level 2 assets.

Formula (2) allows combining creativity and strategic ambitions (motivation) of the management personnel of a credit institution through the use of a process approach in the implementation of innovation strategies [5].

Compared to the purely expert approach, the proposed method has several advantages, since it allows an expert and high-quality set of competition assets and their subsequent impact on the performance of banks to be translated into the language of quantitative measurements, i.e. calculate numerically the integral indicator of their success in competition (Table 3).

In this case, for specialists of the department of strategic development and management of a credit institution, real opportunities appear at the stage of pre-project development to form and select options for innovation strategies for different conditions and market segments $[6,7,8]$. 
Table 3. The technology of calculating the integral indicator of the efficiency of introduction of innovation strategies.

\begin{tabular}{|c|c|c|c|c|c|c|c|c|c|c|}
\hline \multirow{2}{*}{$\begin{array}{l}\text { Compet } \\
\text { ition } \\
\text { assets }\end{array}$} & \multirow{2}{*}{$\begin{array}{l}\text { Compet } \\
\text { itive } \\
\text { factors } \\
\text { include } \\
\text { d in } \\
\text { strategi } \\
\text { es }\end{array}$} & \multirow{2}{*}{$\begin{array}{l}\text { Prior } \\
\text { ity } \\
\text { level } \\
\text { of } \\
\text { the } \\
\text { facto } \\
\text { r (a) }\end{array}$} & \multicolumn{2}{|c|}{$\begin{array}{l}\text { Degree of } \\
\text { implement } \\
\text { ation in the } \\
\text { short term } \\
\text { (from } 1 \text { to } \\
5 \text { points) }\end{array}$} & \multicolumn{2}{|c|}{$\begin{array}{l}\text { Integral } \\
\text { estimate }\end{array}$} & \multicolumn{2}{|c|}{$\begin{array}{c}\text { Maximum } \\
\text { possible } \\
\text { estimate }\end{array}$} & \multirow{2}{*}{$\begin{array}{c}\text { Asset } \\
\text { efficienc } \\
y\end{array}$} & \multirow{2}{*}{$\begin{array}{l}\text { Integral } \\
\text { estimat } \\
\text { e of the } \\
\text { use of } \\
\text { compet } \\
\text { ition } \\
\text { assets, } \\
\text { (\%) }\end{array}$} \\
\hline & & & $\begin{array}{l}\text { estim } \\
\text { ate b }\end{array}$ & $\begin{array}{l}\mathrm{m} \\
\mathrm{ax} \\
\mathrm{b}_{\mathrm{m}} \\
\mathrm{ax}\end{array}$ & $\begin{array}{l}\text { estim } \\
\text { ate } \\
\mathrm{a} * \mathrm{~b}\end{array}$ & $\begin{array}{c}\text { tot } \\
\text { al } \\
\mathrm{a}^{*} \\
\mathrm{~b}\end{array}$ & $\begin{array}{l}\text { estim } \\
\text { ate } \\
\mathrm{a}^{*} \\
\mathrm{~b}_{\max }\end{array}$ & $\begin{array}{c}\text { tot } \\
\mathrm{al} \\
\mathrm{a} \\
{ }^{\mathrm{b}} \\
\mathrm{max}\end{array}$ & & \\
\hline \multirow{4}{*}{$\begin{array}{c}\text { Level } 1 \\
\text { assets }\end{array}$} & $\mathrm{F}_{1}$ & 6 & 2 & 5 & 12 & \multirow{4}{*}{45} & 30 & \multirow{4}{*}{$\begin{array}{c}12 \\
5\end{array}$} & \multirow{4}{*}{$\begin{array}{c}45 / 125= \\
0.36 * 100 \\
=40 \%\end{array}$} & \multirow{12}{*}{$\begin{array}{c}\mathrm{K}= \\
(45+12 \\
5) / \\
(186+3 \\
60)= \\
0.31 * 1 \\
00= \\
31 \%\end{array}$} \\
\hline & $\mathrm{F}_{2}$ & 7 & 3 & 5 & 21 & & 35 & & & \\
\hline & $\mathrm{F}_{3}$ & 6 & 1 & 5 & 6 & & 30 & & & \\
\hline & $\mathrm{F}_{4}$ & 6 & 1 & 5 & 6 & & 30 & & & \\
\hline \multirow{8}{*}{$\begin{array}{c}\text { Level } 1 \\
\text { and } \\
\text { Level } 2 \\
\text { assets }\end{array}$} & $\mathrm{F}_{1}$ & 6 & 2 & 5 & 12 & \multirow{8}{*}{$\begin{array}{c}18 \\
6\end{array}$} & 30 & \multirow{8}{*}{$\begin{array}{c}36 \\
0\end{array}$} & \multirow{8}{*}{$\begin{array}{c}186 / 360 \\
= \\
0.2 * 100 \\
=52 \%\end{array}$} & \\
\hline & $\mathrm{F}_{2}$ & 7 & 3 & 5 & 21 & & 35 & & & \\
\hline & $\mathrm{F}_{3}$ & 6 & 1 & 5 & 6 & & 30 & & & \\
\hline & $\mathrm{F}_{4}$ & 6 & 1 & 5 & 6 & & 30 & & & \\
\hline & $\mathrm{F}_{5}$ & 14 & 3 & 5 & 42 & & 70 & & & \\
\hline & $\mathrm{F}_{6}$ & 13 & 3 & 5 & 39 & & 65 & & & \\
\hline & $\mathrm{F}_{7}$ & 11 & 3 & 5 & 33 & & 55 & & & \\
\hline & $\mathrm{F}_{8}$ & 9 & 3 & 5 & 27 & & 45 & & & \\
\hline
\end{tabular}

The proposed method allows the analyst of the department of strategic management and development of a credit institution to record possible deviations when they occur, to establish the reasons for deviation from the adopted schedule, to determine what control actions should be taken as part of the correction of achieved in the next stage.

\section{Discussion}

Managerial innovations in the banking sector of the economy, for the most part, affect the interests of a large number of interdependent market actors acting as organizational barriers to copying and directly transferring effective innovations to the competitive field of other commercial structures. Under the conditions of systemic transformations and modernization of the banking sector of the economy, this turned out to be the most preferable competitive advantage among other innovations used by credit institutions operating in an environment with a high level of competition.

\section{Conclusion}

The main tool of competition in the markets of banking products, in contrast to the real sector of the economy, is not technological (technical) dominance, but the provision of services to customers and the expected value of a banking product for less cost and in a short time. Here, an increased level of value of banking product is formed due to its high quality and low cost of after-sales service. This allows credit institutions to form modern innovation strategies of their development and, at the same time, to instil on this basis a desirable and risk-free brand of a credit institution into their customers. 


\section{References}

1. N.F. Permichev, Y.A. Tretyakova, Upravleniye ekonomicheskimi si-stemami, elektronnyy nauchnyy zhurnal 4(40) (2012)

2. N.B. Safronova, A.R. Urubkov, A.S. Budakov, M. Myltsev, Serbian journal of management 11(2), 261-273 (2016) ISSN: 1452-4864 (print), 2217-7159 (online)

3. A.K. Orlov, I.Y. Chubarkina, MATEC Web of Conferences 106, 08015 (2017)

4. V. Gasilov, N. Anisimova, I. Provotorov, MATEC Web of Conferences 106, 08035 (2017) DOI: 10.1051/mateconf/ 201710608035

5. A.F. Sandvall, E.O. Ahlgren, T. Ekvall, Energy Strategy Reviews 18, 212-223 (2017)

6. S.V. Domnina, E.V. Savoskina, N.V. Shekhova, Procedia Engineering 153, 741-746 (2016)

7. O.M. Khudolii, O.V. Ivashchenko, S.S. Iermakov, O.G. Rumba, Science of Gymnastics Journal 8, 215-228 (2016)

8. B. Alexander, Journal of Physical Education and Sport 15, 417-425 (2015) doi:10.7752/jpes.2015.03062 